\title{
Going Blended: New Challenges for Second Generation L2 Tutors
}

\author{
Elke Nissen, Elena Tea \\ Lidilem, Université Stendhal - Grenoble 3 (France) \\ Elke.Nissen@u-grenoble3.fr, Elena.Tea@u-grenoble3.fr
}

\begin{abstract}
This study explores how second generation tutors within blended learning courses link the face-to-face and online course modalities - in their representations as well as through their pedagogical activities - and which aspects help them to feel involved in the course. The methodology used is a qualitative analysis of interviews with seven tutors of three different blended learning courses. The results show that most tutors indeed had difficulties gaining a deeper insight into the course design: they considered the face-toface modality to be the central one, just as in a traditional L2 course (whereas course design was centred on the online modality), and therefore rarely played their role as online tutors. Moreover, their understanding of the courses' taskbased approach appeared to be limited. Nevertheless, the majority of the tutors managed to feel involved in the course, which shows the importance of additional factors in defining their relationship to the course. We identified eight other factors, which are partly due to the intense use of ICT within the course (as shown by a comparison with two additional interviews with elearning-tutors), and partly depend specifically on the blended learning mode. This study furthers our understanding of difficulties tutors can have and what support they require within blended language learning settings, although further research will be needed in order to permit greater generalisation.
\end{abstract}

Key-words: Blended learning; tutor; second generation tuition; face-to-face modality; e-learning modality.

\section{Introduction}

\subsection{Context}

Over the last few years, blended learning solutions have become more and more frequent (Singh, 2003; Bonk \& Graham, 2006; MacDonald, 2008; Means et al., 2009). This also applies to blended L2-training (Hauck \& Stickler 2006: 467).

Today, even in small institutions, course designers are no longer the only teachers, trainers or tutors who play a role in these blended learning courses. New people are beginning to play these roles and have to find their place within these sometimes complex courses. We will refer to these people who did not design the course as second generation tutors. Even though the combination of face-to-face and 
distance sessions can benefit learners (Means et al., 2009), it raises new questions for teachers and tutors. While there has been a large array of research on e-learning design, learning and tutoring at a distance over the past 20 years (e.g. Jacquinot, 1993; Jézégou, 1998; Bernard, 1999; Henri \& Lundgren-Cayrol, 2001; Staddon 2001), there is much less focus on blended learning, and still less on blended language learning (except e.g. Neumeier, 2005). And, to our knowledge, no research has been carried out on second generation blended learning tutoring yet. Here, the issue is no longer how best to enable students to learn at a distance, but rather how best to allow them to benefit from this double modality combining face-to-face and distance sessions.

The following research questions thus arise and will be addressed in the present paper. What role does each modality play in the eyes of the teachers / tutors and how do they combine them? Do they consider them as a whole? How do they manage to make the courses their own, even if they did not design them?

\subsection{Definition of Blended Learning}

Several studies have defined the term "blended learning" as referring to particular forms of teaching with technology (e.g. Whitelock \& Jelfs, 2003; Singh, 2003; Kerres $\&$ De Witt, 2003). However, within the array of different definitions available, the elements that can be mixed to create blended learning are variously stressed.

Therefore "blended learning" can be seen as the mixing of e-learning with traditional learning (Thorne, 2002), as online learning combined with face-to-face (Graham, 2006). We can also find that the purpose of "blended learning" is the mixing of different media, the combination of different modes of web-based technology, or the mixing of different contexts within which learning takes place (Rossett et al., 2003). Some of the definitions suggest the idea that what needs to be blended in "blended learning" are various kinds of intended learning outcomes 
(learning objectives), or different pedagogical approaches like constructivism, behaviourism and cognitivism (Driscoll, 2002). Here, we refer to "blended learning" as the combination of distance and face-to-face learning modalities within a setting where they complete each other and are sustained by a tutor. Moreover, the blended learning settings we analyse in this paper are designed in a task-based approach ${ }^{1}$. Within these different types of what is nevertheless unanimously called blended learning, various research questions have been addressed. Several publications focus on how to build effective courses (MacDonald \& McAteer, 2003; Bersin, 2004 ; Saunders \& Werner, 2004; Neumeier, 2005; Bañados, 2006; Allan, 2007; MacDonald, 2008; Soubrié 2008; Lignon \& Tea, 2010; Rösler \& Würffel, 2010), or point out the advantages of blended learning modalities (Murphy, 2003; Garrison \& Kanuka, 2004; Rovai \& Jordan, 2004; Romano et al., 2005; Motteram, 2006; Dalsgaard \& Godsk, 2007; Hughes, 2007). Some work focuses on the reasons why experts in instructional technology use blended learning (Bonk \& Graham, 2006). Others compare the effectiveness of distance and blended learning environments (Harker \& Koutsantoni, 2005) or investigate the students' point of view (Ginns \& Ellis, 2007; Strake, 2007; Deschryver, 2008; Giugni, 2008; Nissen, 2009a). A few studies focus on the tutors' role, but they concentrate either on the roles attributed to tutors in the different course modalities (Nissen, 2011), compared to an e-learning course (Nissen, 2009b), or they aim at improving the blended learning course in one specific institution (Guillet \& Roupié, 2008).

We define a task according to the Common European Framework of Reference for Languages (Council of Europe, 2001) as an object-oriented action with an observable result, that can imply the use of language but does not necessarily or entirely do so, and that is part of the learners' (possible) social context: every day life, studies, work, etc. 


\section{The Study}

The objective of our study is to understand how second generation tutors on the one hand perceive links and on the other hand create links between the different blended learning course modalities. A further objective is to explore what helps them make a blended learning course, which they did not design, their own.

\subsection{Data Collection and Method of Analysis}

In order to answer these research questions, we interviewed seven teachers and tutors who participated in three different blended language learning courses, all at university level. We also interviewed two tutors of an e-learning course that was delivered exclusively online, so that we could distinguish between statements that were due to the blending of learning modalities, and statements that were more generally due to the intense use of ICT within a language course. This e-learning course is based on the same pedagogical approach as the online part of two of the blended learning courses (cf. section 2.2.), and is therefore comparable to the others.

The nine semi-guided interviews lasted between 22 and 60 minutes; 354 minutes in total. The main questions we tackled dealt with the role played by the second generation tutors in the course, and more specifically in each learning modality. We also evoked the difficulties they encountered and what kind of help they found, who they worked with (e.g. other tutors, course coordinators, etc.) and how they worked with them, how they considered the course modalities to be connected and how they actively linked them when working with the students. We also asked whether they had former experience in e-learning or blended learning. Our method of interview analysis is qualitative analysis.

\begin{tabular}{|l|l|l|l|}
\hline $\begin{array}{l}\text { Course 1 } \\
\text { (blended learning) }\end{array}$ & $\begin{array}{l}\text { Course 2 } \\
\text { (blended learning) }\end{array}$ & $\begin{array}{l}\text { Course 3 } \\
\text { (blended learning) }\end{array}$ & $\begin{array}{l}\text { Course 4 } \\
\text { (e-learning) }\end{array}$ \\
\hline $\begin{array}{l}\text { Tutor 1A (41'20) } \\
\text { Tutor 1B (30'10) }\end{array}$ & $\begin{array}{l}\text { Tutor 2A (41'35) } \\
\text { Tutor 2B (59'58) }\end{array}$ & Tutor 3A (39'15) & $\begin{array}{l}\text { Tutor 4A (44'27) } \\
\text { Tutor 4B (28'45) }\end{array}$
\end{tabular}


\begin{tabular}{|l|l}
\hline Tutor 1C (21'56) & Tutor 2C (48'57)
\end{tabular}

Table 1. Length of the interviews with tutors.

All tutors but one agreed to be interviewed, so we can base our analysis on a relatively complete range of views of the different tutors who were involved in a same course. At the same time, we can observe tutors' perceptions within three different blended learning courses. Although this will not allow us to generalize from the results, it nevertheless provides a broader perspective than would be afforded by a single case study.

\subsection{Description of the Courses}

The courses we shall examine are all L2 courses for specialists of other disciplines, provided by Stendhal University (Grenoble, France) during the first semester 2009/2010. They were designed and organized by the Lansad (languages for specialists of other disciplines) department, in the context of an Inter-University Language Project (PIUL) in 2009-2010. The platform used for the distance part of all these courses is Esprit (Quintin et al., 2001), which was co-developed by the universities of Mons (Belgium) and Grenoble (France). It allows pedagogical activities to be offered in both individual and collective learning modes.

The teachers and tutors involved in our blended learning programs have various different statuses. Some are permanent teachers, the majority of them are teachers on one-year contracts and others are replacement teachers. However, they are all native speakers of the language they teach. Their technical competence is reasonable as they all have some experience in teaching using a computer.

Two blended learning courses (course 1 and course 2) are English courses, designed on the same model. They both combine three modalities: individual online work on a learning platform, face-to-face sessions in large groups of 18 students, and 
conversation workshops in smaller groups of 6 students. Several people are involved in these courses: two course coordinators, a course designer for each course, teachers for the face-to-face sessions, tutors for the conversation workshops, and online tutors. Since it is often the same people who are involved as teachers (in face-to-face sessions) and at the same time as tutors (in conversation workshops or online), in the present paper we shall refer to all of them as "tutors".

Although courses 1 and 2 are very similar, some key differences must be mentioned: they are designed for different special purposes (Cities and Environment vs. Economy and Business Administration); they target students of different university levels (students in second-year Masters classes at the Grenoble Institute of Urbanism vs. first-year students in the Economics Faculty at Pierre-Mendès-France University in Grenoble); and the number of hours in each learning modality differs: figure 1 shows the hours for both courses, (with the number of hours for course 2 in italics and in parentheses).

The three modalities are all scheduled regularly during the semester. Between 6 and 11 units appear on an online learning platform. After preparatory activities with immediate automatic feedback, each unit ends with a task to be accomplished: written tasks that the students hand in via the platform or oral tasks that are carried out during the conversation workshops. Thus, the latter are totally integrated into the online units. Regarding the face-to-face sessions, no precise content is given to the tutors as the course coordinators wanted to give them space for their own ideas. 


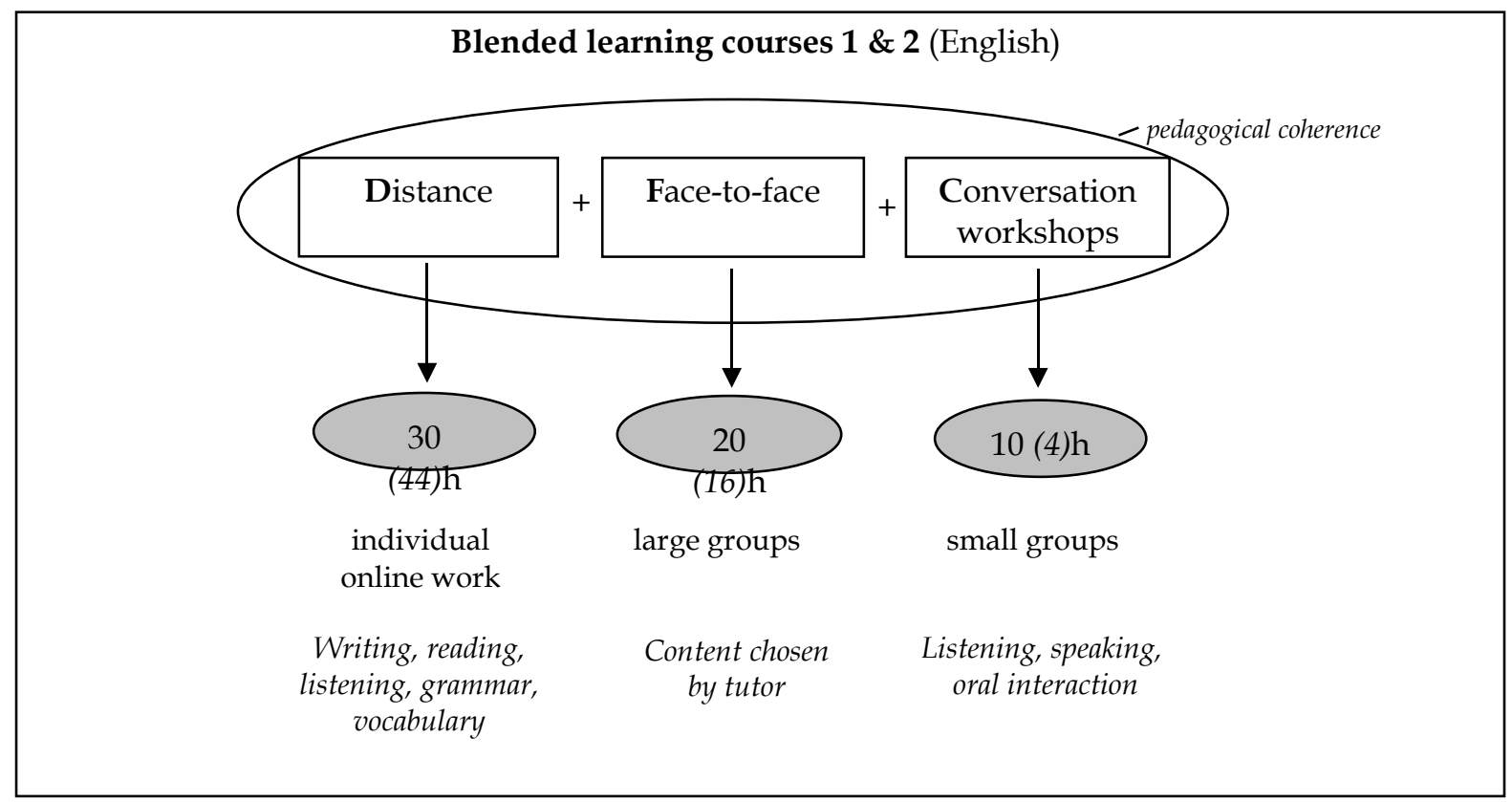

Figure 1. Model of course 1, English for Cities and Environment (level B1 or B2), and course 2, Economy and Business Administration (level A2).

Course 3 is a German course. It is one of the German courses for students of other disciplines that can be taken by students from any university in Grenoble and at any university level. Because far fewer students take German L2-courses, only one session ran at a time (contrary to the English courses 1 and 2, where three or four tutors gave parallel sessions), and therefore there was only one tutor. Similar to courses 1 and 2, the course lasts two semesters. The three learning modalities are interconnected and lead the students to accomplish successive real world tasks within a global simulation. Two major differences can be pointed out between course 3 on the one hand and courses 1 and 2 on the other hand. First, in courses 1 and 2 the tasks are not linked to each other whereas in course 3 the pedagogical scenario clearly links them. Second, course 3 does not include conversation workshops, preferring another way to foster intense language practice: during some of the face-to-face sessions, the students participate in videoconferences with L2-learners in Germany, in small groups from 2 to 4 students. The videoconferencing allows the students to practice oral 
interaction with native speakers and to gather information on their student life, as this is the theme of the course. Videoconferencing and conversation workshops might both be considered as forms of synchronous oral interaction in (very) small groups.

In this course 3 , the course designer also conceived the distance work component as the main modality, but, unlike courses 1 and 2, the students accomplish tasks online in small groups. They also do individual online work on methodological aspects, or grammar, or in direct preparation for the task to be accomplished.

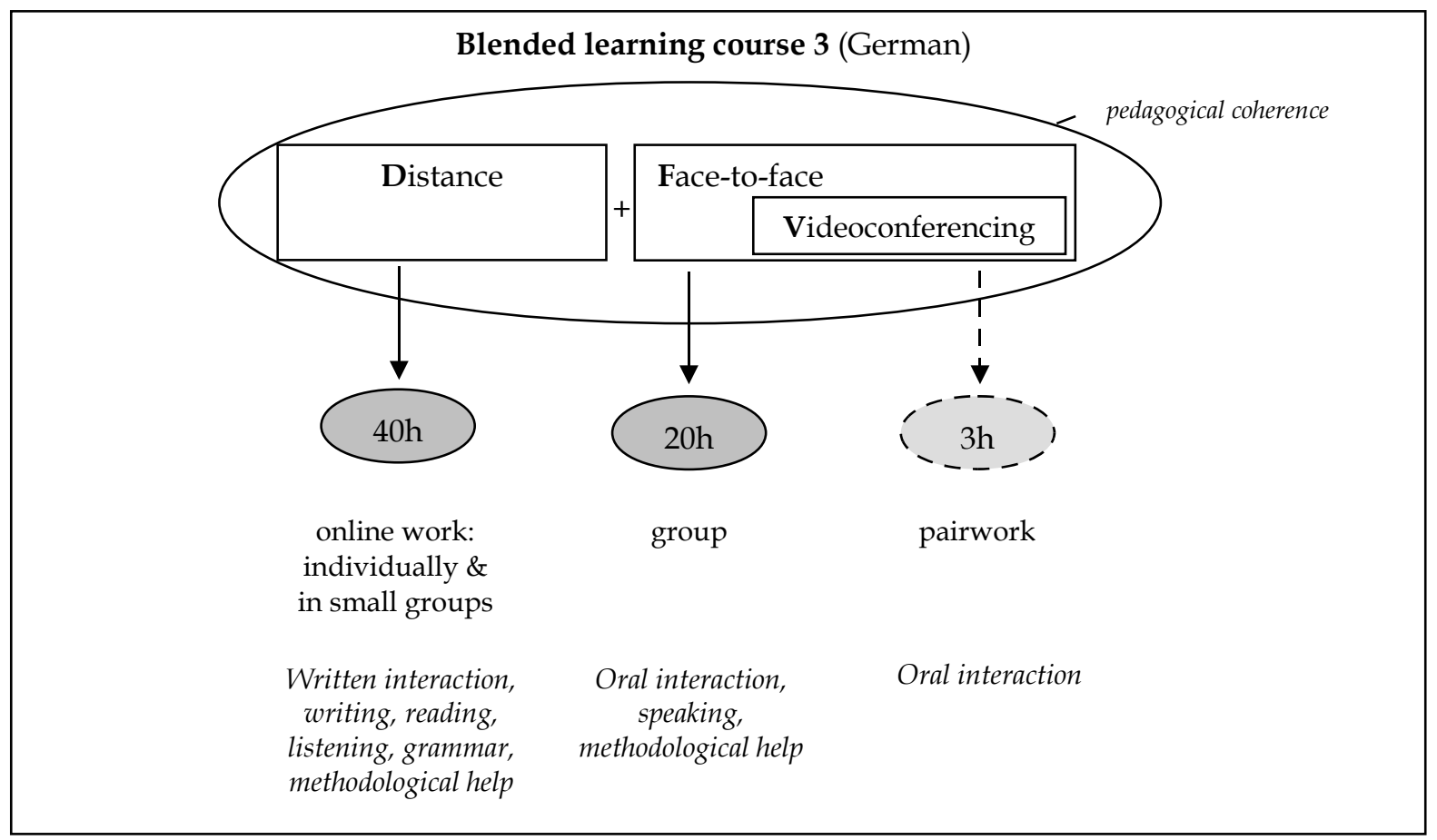

Figure 2. Model of course 3, Student Life in Germany (level B1). 
Course 4 (Distance learning course in English, level A2) targets students attending first-year Masters classes, in scientific and technical faculties, at Joseph Fourier University in Grenoble. It is entirely delivered at a distance and does not include any face-to-face sessions or conversation workshops. However, it is designed on the same model as courses 1 and 2, and has the same coordinators. It also consists of modules on a learning platform where students accomplish and hand in a task at the end of each module. And, again similar to courses 1 and 2, listening and reading activities as well as work on the topic of each module, grammar and vocabulary familiarise students beforehand with the topic of each module.

\section{Results}

The content analysis of our interviews with the tutors of the blended learning courses reveals that most of them consider that they were able to make the blended learning course their own. But the degree to which they consider they were able to do so varies a great deal, as indicated by table 1 .

Two tutors (1A and $2 \mathrm{~A})$ out of the seven are very positive about their integration into the course, two are positive (1B and $2 \mathrm{~B})$, one is uncertain $(3 \mathrm{~A})$ and two are negative (1C and $2 \mathrm{C})$. This diversity shows that the tutors' feeling of involvement is not simply due to the course design itself. Several other elements that have a clear impact upon the level of involvement felt by tutors are recurrent in the interviews.

\begin{tabular}{|lc|c|c|c|c|}
\hline $\begin{array}{l}\text { Feeling of } \\
\text { involvement }\end{array}$ & Course 1 & Course 2 & Course 3 & $\begin{array}{l}\text { Course 4: } \\
\text { (e-learning) }\end{array}$ \\
\hline Very positive ++ & Tutor 1A & Tutor 2A & & Tutor 4A \\
\hline Positive + & Tutor 1B & Tutor 2B & & Tutor 4B \\
\hline Uncertain +- & & & Tutor 3A & \\
\hline Negative - & Tutor 1C & Tutor 2C & & \\
\hline
\end{tabular}

Table 2. Tutors' feeling of involvement in their mediated course. 
In this section, we will first describe the link they make between the different course delivering modalities (at a distance, face-to-face in large groups, and the conversation workshops / the videoconferencing) and how they consider the role they play within these modalities. Second, we will identify the reasons for which they felt integrated or not.

\subsection{What Links do Tutors Perceive and Create between Different Course Delivering Modalities, and what Roles do they Play?}

\subsubsection{How tutors link the three modalities}

Based on our interviews with the tutors, we attempt to draw up a schematic representation of the way in which they relate distance sessions, face-to-face sessions and conversation workshops / videoconferencing (cf. figures 3, 4, and 5). A distinction can be made between passive and active links. The former are those perceived by the tutors but that they do not initiate themselves, while the latter are those that they create themselves when working with the students (we distinguish both kinds of links: in figures 3 and 4 the active ones are underlined).

The three schemas in figure 3 show that the tutors mainly focus on the modalities in which they were actors themselves, and on the way in which these modalities are linked to the others. For instance, tutor 1A, who was solely involved in conversation workshops, creates active links between the workshops and the other two modalities (distance and face-to-face); but she does not mention any link, active or passive, between the latter two.

Her active links are based on grammar and vocabulary: in her workshops, she uses the vocabulary the students have learnt online, allows students to question her on words they encountered in the face-to-face sessions, and tests them on grammar points taught in the latter. She also makes links on an organisational level, intensively exchanging information with the face-to-face tutor, taking a very close look at the 
online activities while preparing the workshops, and transmitting students' comments to the course coordinators. Therefore, she feels she is an intermediary between the face-to-face modality, the distance modality, and the students.

Tutor 1B sees a (passive) topical link between the online contents and the conversation workshops. The active links she makes are based on grammar. In her view, grammar is essential for learning progress, and she therefore mostly teaches grammar in the face-to-face sessions. The grammar points are, for higher level students, those from the online units, and in the same way the grammatical work is generally meant to facilitate the online learning process.

Tutor $1 \mathrm{C}$ does not mention any active link between the three modalities. She only states that the units at a distance prepare the conversation workshops she gives.

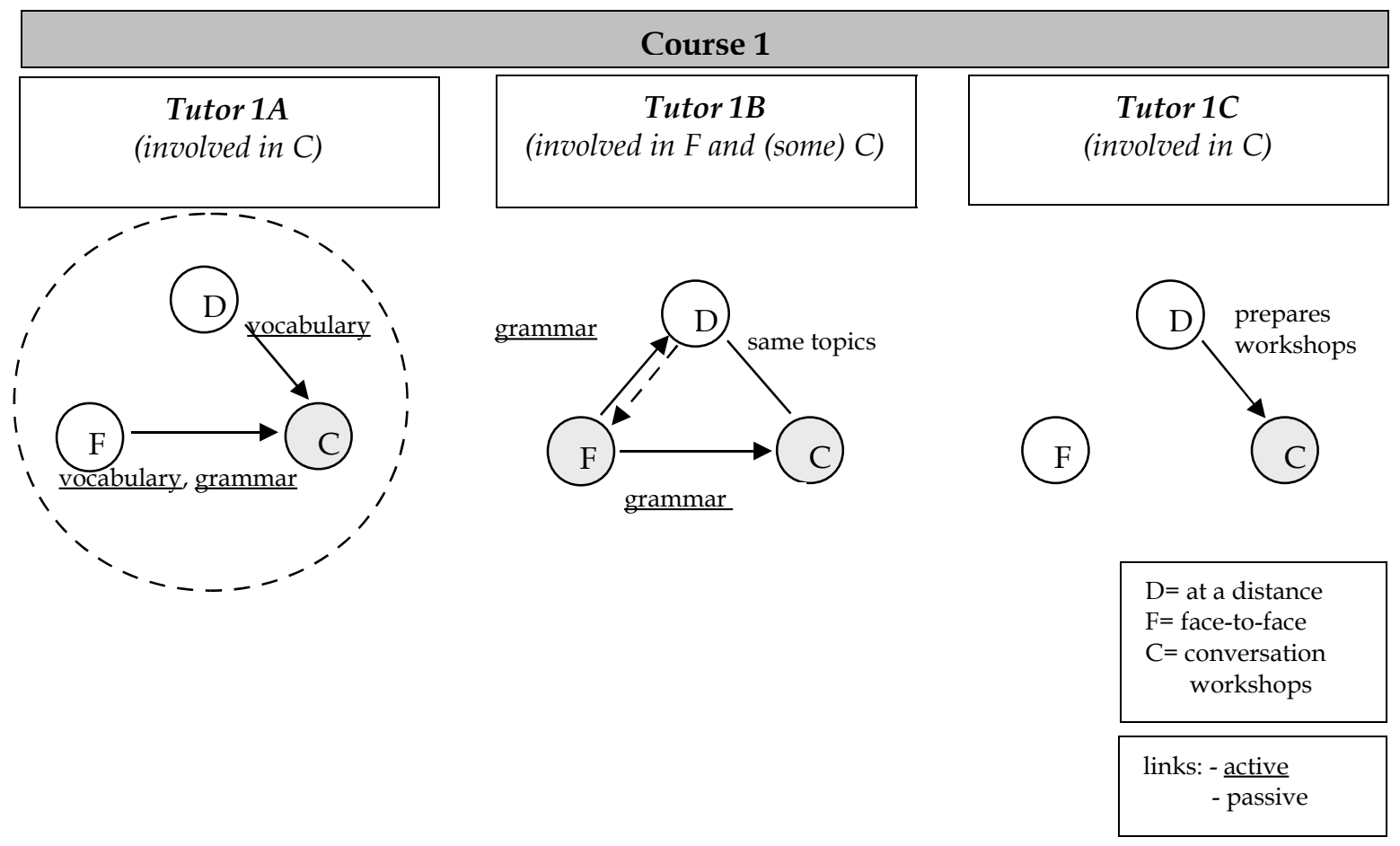

Figure 3. Course 1 tutors' indication of the link between the three modalities (at a distance (D), face-to-face (F), and conversation workshops (C)). 
Tutor 2A states that she had thought about how to relate the different modalities and had finally decided to base the link on grammar, and hence deals in the face-to-face sessions with grammar points from the online units. As figure 4 shows, she does not mention any other active or passive links.

Tutor 2B has a much more complex vision of the relationship between course modalities, and she considers the whole as a coherent system. This different outlook, grounded more in a design perspective, can be better understood in light of the knowledge that she has previously completed a Master's degree in educational technology. Nevertheless, she does not explain precisely why she considers "complementary", on the one hand face-to-face sessions and online units and face-toface sessions and conversation workshops on the other hand. As for the link between the distance modality and the workshops, in the latter the students put into practice what they have understood in the online units.

As most of his counterparts, tutor $2 \mathrm{C}$ actively establishes links based on grammar and vocabulary: he relates the online units on the one hand with the face-toface sessions as well as the workshops. Surprisingly, neither he nor tutor 2A mention any relationship between the face-to-face modality and the workshops. One explanation for this phenomenon could be the course coordinators' general insistence on drawing links with the distance modality, since they consider links between the onsite sessions in big groups (face-to-face sessions) and in small groups (workshops) as more self-evident for the tutors. 


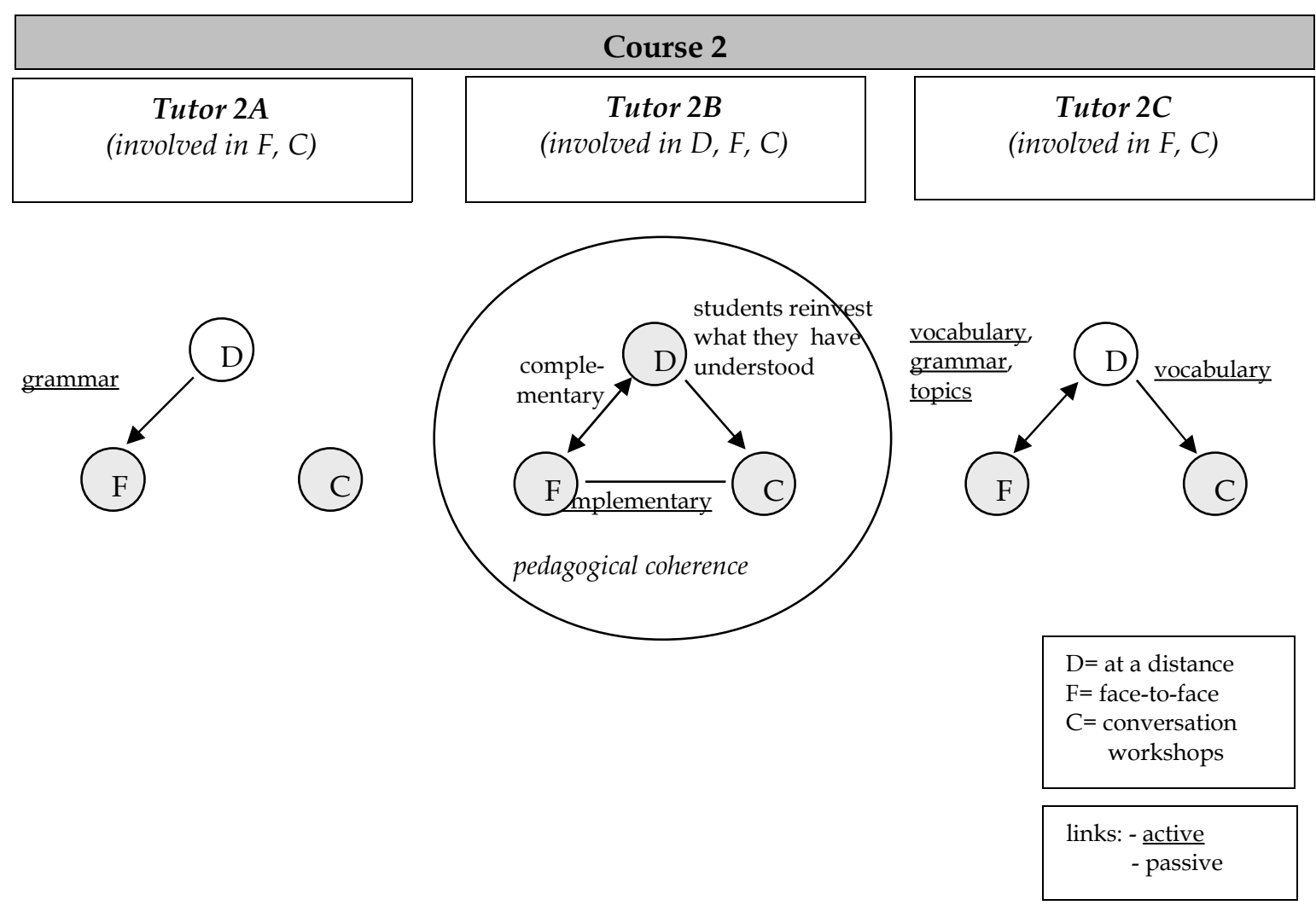

Figure 4. Course 2 tutors' indication of the link between the three modalities (at a distance (D), face-to-face (F), and conversation workshops (C)).

As shown by figure 5, the active links created by tutor $3 \mathrm{~A}$ go from the face-toface modality to the distance modality. Indeed, it is within the face-to-face sessions that she feels most at ease and, in her view, they aim at motivating and preparing students for the work at a distance through methodological training in how to learn. The passive links she sees are also motivational (videoconferencing motivates the students for the whole course), or acquisition-related (within the videoconferencing, students put into practice what they have learnt online and face-to-face). She states that task accomplishment is the focal point in this course, but she also admits her lack of understanding of the different function of the different modalities within this. 


\section{Course 3}

\section{Tutor $3 A$}

(involved in $D, F, V$ )

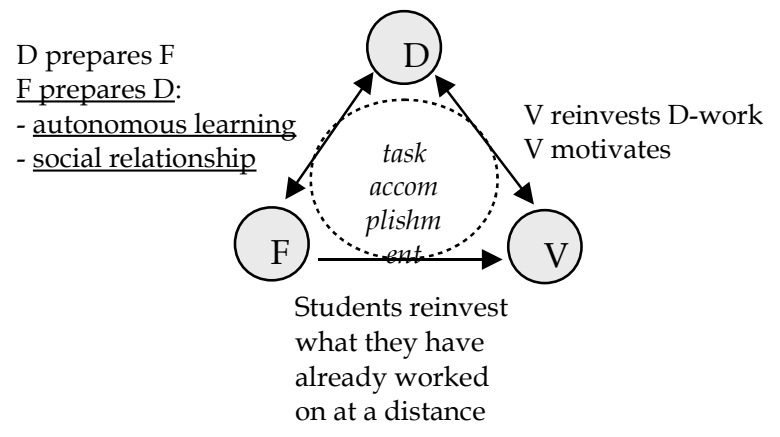

$\mathrm{D}=$ at a distance

$\mathrm{F}=$ face-to-face

$\mathrm{V}=$ videoconferencing

links: - active - passive

Figure 5. Course 3 tutor's indication of the link between the three modalities (at a distance (D), face-to-face (F), and videoconferencing (C)).

\subsubsection{Tutors' involvement in the three modalities}

\subsubsection{Face-to-face sessions}

As shown by section 3.1.1, the links the tutors draw between different course modalities are mostly based on grammar and vocabulary, or sometimes on common topics. Some of these links are made while preparing the sessions. Others are made while delivering the sessions: within the face-to-face sessions or the conversation workshops, they give students time to ask questions on grammar and vocabulary, or they themselves question or test students.

Grammar appears to be regarded as highly important, not only for the links established, but also as the basis for the face-to-face sessions. Tutor 1A, for instance, calls these sessions "grammar classes", and in fact tutors 1B, 2A and 2C mainly focus on grammar. Other, apparently secondary, aspects they address face-to-face are: culture, reading comprehension, listening comprehension, and vocabulary; tutor $2 \mathrm{C}$ also mentions oral interaction. 
Unlike these grammar-centered sessions, tutor 2B works on oral expression, oral interaction, and some written expression. In order to allow students to practice oral interaction even more, she divides the face-to-face groups into smaller groups. She also emphasizes methodological cognitive aspects: she asks the students to keep their own vocabulary notebook, and she works on the methodology of listening comprehension.

Tutor 3A also uses face-to-face sessions to work on methodological aspects, although quite different ones: she took over and extended, in the face-to-face context, some work from the platform on "what kind of a learner am I?". She also aims at creating a positive working environment and establishing social relationships with students during the face-to-face sessions, so that they feel involved in the course and do not give up during the online phases.

We can draw a parallel between the greater complexity of links between course modalities perceived by tutors $2 \mathrm{~B}$ and $3 \mathrm{~A}$ and the fact that they are the only ones who address methodological aspects. Indeed, these two tutors are the only ones who have previous experience in course design including an online platform, and tutor $2 \mathrm{~B}$, at least, had previously thought about how to combine face-to-face and online sessions.

\subsubsection{Conversation workshops}

Regarding conversation workshops, all tutors (of courses 1 and 2, since course 3 employs videoconferencing instead) agree that they aim at intensive language practice. They have a clear vision of their role within workshops. Thus, they take a back seat in order to let the students speak as much as possible, they moderate (tutors $1 \mathrm{~B}, 2 \mathrm{~B})$, they use the preparation sheets on the platform in order to make the students talk (tutor $2 \mathrm{C}$ ), they encourage students to speak (1B, 1C), they give vocabulary hints 
(1A, 1B), they correct (1B), and they incite students to employ words and content they had understood when working online. They know how a conversation workshop functions, and they know students prepare them using the workshop preparation sheets on the platform.

\subsubsection{Online tuition}

Conversely, it is much less clear to them what exactly their role as an online tutor should entail. It is striking that whereas all these tutors were supposed to follow the students' work online - as stated by the course coordinators -, figures 3, 4, and 5 show that only tutors $2 \mathrm{~B}$ and $3 \mathrm{~A}$ indicate that they actually did so. Tutor $2 \mathrm{~B}$ talks very clearly about the way she tutors students online individually and what she thinks about assessing online tasks. Tutor 3A only talks about online tuition in negative terms: she underlines its difficulties, for instance the difficulty of staying in touch with students at a distance.

None of the other tutors claimed to have played a role as an online tutor. Nevertheless, tutors 1B and 2C marked written tasks handed in by the students via the platform or via e-mail. However, they do not seem to consider this as being part of the role of an online tutor. For most of the tutors, online tuition is not incumbent upon them. "Online tuition, no, I never did it... I could not even tell you how it works", states tutor 1B.

\subsubsection{Discussion of tutors' roles and perceptions regarding course modalities}

When we compare how involved tutors felt, as indicated in table 2 , and the number of active and passive links these tutors make between the three course modalities, or the complexity of these links (cf. section 3.1.), no direct correlation can be seen. With the exception of tutor $1 \mathrm{C}$, who does not draw any active link at all and, in parallel, states 
she had not been able to make the course her own. For all the others, neither the number of active links they make between course modalities, nor the complexity of their understanding of the course model, can directly explain their feeling of involvement. Thus, the way tutors relate course modalities is only one aspect among others that determine this involvement.

Another important aspect appears in tutor 3A's statements: the understanding of the task-based approach. Course 3 is task-based, and the tasks as well as the methodological approach require some understanding of how to focus a course, through different modalities, on task accomplishment and acquiring abilities in order to accomplish these tasks. Although tutor $3 \mathrm{~A}$ clearly perceived that the course was task-based, it was too complex to allow her to feel she was able to handle it.

In courses 1 and 2 , each unit also ends with a writing task or an oral task, the latter being completed during a workshop. Although the tasks are smaller and the whole course less complex, as we indicated in section 2.2., the courses are still taskbased and their design links at least the distance modality and the workshops through tasks. Hence, it is striking that none of the tutors for these courses even mention tasks as an existing link between course modalities, and we can therefore doubt their understanding of the task-based approach. They rather make (active) links and perceive (passive) links based on grammar, vocabulary and sometimes topics.

Although tutor 1B did perceive that the online units determine the whole content of the blended course, what section 3.1.2. shows is that the tutors nevertheless do not consider the distance modality to be important. Different reasons can be found for this. Firstly, in their view the distance modality does not allow for the element that they consider to be important, that is to say oral skills (cf. tutors 1A, 2A), because only the face-to-face modality is "lively and spontaneous" (tutor 1A) (although they 
insist a lot on grammar and not always on oral skills face-to-face either). Secondly, at a distance, it is difficult to establish social relationships (tutor 3A).

\subsection{What Helps Tutors Feel Involved in a Blended Learning Course?}

As we stated before, most of the tutors felt they were able to make the course their own. However, some did not. We identified two primary factors above (in section 3.1.1.) that allow us to explain the varying involvement of the tutors: the way they actively and passively relate course modalities, and their understanding of the course design's task-based approach. This part of our paper will outline eight other recurrent factors that were identified through our interviews. In order to see whether they are exclusively linked to blended learning courses (or if they also apply to e-learning courses), we will make comparisons with the statements made by the e-learning tutors.

\subsubsection{Accepting to spend time familiarizing themselves with course content}

To be able to feel involved, several tutors feel the need to look in detail at the online course content and activities, or even complete the online activities themselves. Tutor 2A does so. She states: "Just go on it, look at everything and then when you are familiar with the contents, link up these elements. Then I felt I was a part of it because I linked up parts of it."

Another tutor, 1A, while preparing her conversation workshops, did the same with the activities completed in the face-to-face class, but in a less detailed way with the online activities. It still shows her involvement in the course, but at the same time it reveals the greater importance she sees in face-to-face teaching than in the online part of this blended learning course. 
The need to know the course content in detail is not exclusively linked to blended learning courses. It can be felt by any tutor who did not design the content: one of the two tutors of an e-learning course (4A) also familiarized herself in detail with the online content in order to adapt her tuition to it.

\subsubsection{Appreciating course content}

Another element that helps the tutors truly accept to get involved in a blended learning course - perhaps in the same way as in any kind of course, and our interviews with e-learning tutors confirm this - is their appreciation of the course content. Two of the tutors who felt involved in the blended learning course mention the quality of the online content $(2 \mathrm{~A}$ and $2 \mathrm{~B})$. Tutor $2 \mathrm{~A}$ indicates that she globally appreciates the great variety of the online content and the quality of the audio and video documents on the platform, which are up to date and appealing. Nevertheless, the topics of some of the units interest her more than others, and she comments that "it can be trickier to work on [several] subjects rather than on those that you like".

\subsubsection{Obtaining help easily and efficiently (from the course coordinators)}

Blended learning courses 1 and 2, and the e-learning course on which our study is based, all had the same two course coordinators. Tutors highly appreciate the great availability of the coordinators, as well as the speed and efficiency of their responses. For instance, tutor $2 \mathrm{~B}$ notes that whenever she had a technical problem, she simply contacted the relevant coordinator, and he always found a solution. Tutor $1 \mathrm{~B}$ states more globally, regarding not only technical help but general help: "What really has to be maintained is the great availability of the interlocutors and the quality of their responses. I really found this fabulous. (...) Whenever you had a problem, you just 
had to pick up your phone or write an email and at most two days later, [a coordinator] had given you an answer or even found a solution".

\subsubsection{Feeling integrated into a team}

This factor goes further than simply obtaining answers to questions (as explained in 3.2.3.). It is a very important element and depends specifically on the blended learning mode where several tutors are involved in one course. On the contrary, when there is no course content to elaborate and when one single tutor is involved for one group of learners, discussion with other tutors of the same course is considered not to be absolutely necessary, as evidenced by our interview with e-learning tutor $4 \mathrm{~A}$.

The blended learning tutors who are most positive about their involvement in the course are also those who consider themselves to be part of both a tutor team and a team with actors at different levels of the course (1A and $2 \mathrm{~A})$. The tutors who were not integrated into a team felt little (3A) or no (1C) involvement in their course. One counterexample is tutor $2 \mathrm{C}$, who did not feel involved in his course either, despite sharing the same course documents and activities with two other face-to-face tutors of other groups within the same course - but this person prefers to teach with textbooks, or ready-made documents, rather than elaborating content and activities, alone or with others (cf. below). This appears to be the reason why teamwork is less important for him than for the others; furthermore, in his case, contact with the other tutors seems to have been limited to sharing documents.

\subsubsection{A team of actors at different levels of the course (course designers, coordinators, secretaries, students)}

Within the quite complex blended learning courses we are considering in this study, tutor $1 \mathrm{~A}$ emphasizes the importance of good communication between the actors at all levels of the course. She never felt isolated, because the coordinators let the tutors 
express their ideas, and took them into account, and because they informed them about any changes. She was in contact not only with the coordinators, but also with a large number of other individuals: the coordinators, the students, the university secretary, an interuniversity secretary, the face-to-face tutor, the students and finally also the course designer. "We were all so much in contact and really, I had the feeling we all worked as a team".

In the same way, tutor 2B states she was able to feel involved in the course because the different actors worked as a team - the course designer, the coordinators, herself as a tutor and the learners - and she explicitly felt like one of these actors: "We did not simply use a tool (as I did before with other readymade learning tools), we were a team where everyone played a role".

Two of the tutors $(2 \mathrm{~A}, 3 \mathrm{~A})$ underscore the importance of contact with the course designers. Tutor $2 \mathrm{~A}$ "really liked the course, very probably because [she] know $[\mathrm{s}]$ and trust[s] the people who designed it". In parallel, tutor $3 \mathrm{~A}$ greatly regrets she was not able to exchange with the course designer who was on maternity leave. She received advice, explanations and useful documents from her at the beginning, in complement to the ready-made online part of the course. Afterwards, however, she "managed the course all alone" and could not ask questions of anyone, because there were no parallel blended courses with other tutors for this language. She would have liked to be able to ask the course designer questions in order to better "understand the logic behind the course and the course structure (...). Of course, if you can discuss a situation with someone, it's better, it helps."

\subsubsection{A team of tutors}

As we stated above, it is possible to draw a clear parallel between how the tutors think they were able to make the course their own, and their degree of teamwork with other 
tutors. Thus, tutors $1 \mathrm{~A}$ and $2 \mathrm{~A}$ who feel very much involved in the course, say they worked a good deal with at least one of the other tutors of their course. Tutor 1B, who is quite positive about her involvement in the course, provided information to the workshop tutor (regarding what she was going to do during the face-to-face sessions) more than she actually cooperated with her. Tutor $1 \mathrm{C}$ who did not feel at all involved did not work in a team with other tutors either.

We showed above (cf. 3.2.4.1.) that tutor $2 \mathrm{C}$ worked in close cooperation with actors on other levels of the course. She also tried to have more contact with the other tutors, but the meetings she initiated took place quite late during the course. She notes that, in order to achieve an even better coherence of the whole course, teamwork between the tutors of the three learning modes (online, face-to-face sessions and conversation workshops), would have been helpful.

\subsubsection{Working closely with the other actors of the course}

While teamwork enhances the feeling of involvement, geographical proximity can enhance teamwork on two levels. First, regarding teamwork between tutors, tutor $2 \mathrm{C}$ states that he delivered his courses at the same time and in a classroom right beside two other tutors. It was these tutors who tried to coordinate their courses whereas they did not work with another tutor of the same course (2B), who taught her courses another day.

Second, regarding teamwork with the coordinators, several tutors who delivered courses close to the coordinators' office on the campus, regularly (2A) or sometimes (1B) knocked on their office door in order to work with them. Nevertheless, motivation can compensate geographical distance: Tutor 1A sometimes telephoned, and tutor $2 \mathrm{~B}$ had regular online contact with the coordinators. 


\subsubsection{Feeling free within a given framework / taking initiatives}

The coordinators deliberately let course 1 and 2's tutors decide on their own what they wanted to address during the face-to-face sessions, and to design these courses themselves, providing they took into account the online content. Almost all of the tutors state that this helped them to feel free and to be able to make the course their own. For instance, tutor 1B notes: "There was a framework and at the same time, I could work on what I wanted and how I wanted within this framework."

Some tutors went further and took initiatives even where the coordinators had not foreseen this. Thus, tutor $2 \mathrm{~A}$ modified content even for the conversation workshops for which detailed preparation sheets had been designed. For example, she had the students work on a subject she thought was more appropriate just before a test. Tutor 3A emphasized autonomous learning during the face-to-face sessions when she felt the students would manage the course better if they knew more about their own learning style. Tutor $2 \mathrm{~B}$ took numerous initiatives. In addition to the ones already mentioned, she also decided to give one session in a computer lab when she became aware of the technical problems encountered by students, and she did not give any marks online in the beginning when she felt her role was essentially to support the students.

\subsubsection{Being able to influence course design}

None of the tutors interviewed had designed the online part of the course.

Nevertheless, one person (2A) had designed preparation sheets for the conversation workshops, which probably enhanced her feeling of involvement in the course.

Furthermore, as the universities had ordered courses 1 and 2 very late, the latter were designed at an extremely late stage meaning that, at the end of the year, the designer was only a week or two ahead of the users of the course. Requests for changes could 
therefore easily be taken into consideration, for instance the suggestion to indicate in a footnote the British English version of an American English expression. In turn, this acceptance of their requests contributed to the tutors' feeling of involvement. Tutor 1A states: "At one point I found that the online activities became very difficult. I discussed this with [tutor 1B] who agreed. We talked to the course designer who said: 'Oh, thank you for telling me', and he changed the activities. (...) Everybody always took into account our suggestions."

The statements of tutors $1 \mathrm{C}$ and $3 \mathrm{~A}$ confirm that this involvement in course design is important for tutors' adhesion to the course: both of them felt distanced from the course design and therefore found it difficult to teach within this course. Tutor 1C says: "If I had been more involved in coming up with the workshops [the students] had to prepare, then I think I would have been more like "appropriée" (i.e. better adapted to the situation), but I was kind of distanced from it, so it was kind of like I was one of the students, I just came in and talked basically."

A comparison with online course 4 on this point is not really possible, since it was already designed when the course started. Nevertheless, tutor 4B, who does not like the content, says that if ever this were modified, she would like to participate in the process. This means that it is easier for tutors to feel involved in a computer mediated course if they can at least influence a part of its content - if they are willing to do so. And this is easier within a blended learning course where tutors can decide on their own what and how they teach during face-to-face sessions, than in an online course where many more things are determined in advance. This result confirms our underlying assumption for this study, i.e. that it is more difficult for second generation tutors than for first generation tutors to feel involved in a course, precisely because they did not design it. 


\subsubsection{Feeling comfortable with the use of technical tools}

When many different technical tools are required in a course, this can be a source of stress for tutors. For instance, tutor 3A felt nervous because of the use of the videoconferencing tool (Skype), despite the presence of a technical assistant, and she found the use of software for the production of audio files (Audacity) difficult for the students, although it was explained in detail on the platform.

The use of the platform itself (Esprit) is not seen as being difficult by those who use it often, that is to say the e-learning tutors $4 \mathrm{~A}$ and $4 \mathrm{~B}$. One of them even insists on the ease of its use: "No, no, for me - and I am not talented at using technical things - I think it is really ... it is easy". Whereas for the blended learning tutors who use it irregularly, and for whom adequate initial technical training time was sometimes lacking due to the fact courses 1 and 2 were ordered, and thus designed, at the last minute (tutors were introduced to the platform together with the students), the reactions are not at all the same. Either they ask many technical questions (e.g. tutor 1A), they do not use the platform and forget to play their foreseen role as an online tutor (tutors 1C, 2A), or they reduce its role to that of assessing online tasks (tutor 1C). Some find the use of the online submission tool too complicated and avoid it by asking the students to send their tasks via e-mail (tutor 2C). This shows that adequate initial training specifically for tutors, as is normally implemented when courses are created well ahead of time, and as was the case for the e-learning tutors, is absolutely necessary in order to allow them to take up the online platform and to become fully involved in the online aspects of the course. 


\subsubsection{Summary: Which of these factors are specifically due to the blended learning mode?}

Within the eight factors that allow tutors to have the feeling they were able to make the course their own, which we identified through our interviews and which we indicated in this section 3.2., some are due to the intensive use of ICT within the course: whether tutors accepted to spend time examining closely the online part, whether they appreciated it, whether they obtained help easily and efficiently, mainly for technical issues. Other aspects specifically depend on the blended learning mode, since it is even more complex than a course delivered entirely online: whether tutors felt integrated into a team of peers or of other actors within the course (e.g. a course coordinator, a secretary), whether they felt at ease with the use of technology, whether they felt free to take initiatives within the course, and whether they felt they were able to influence course design.

\section{Conclusion}

In this study, we found that most of the second generation tutors managed to feel involved in the blended learning course. Nevertheless, the majority had trouble understanding the function of the online part of the courses, and their own role within this online part. This is probably due to the fact that these tutors are used to providing traditional face-to-face courses: they do not distinguish between a traditional face-toface session and a face-to-face session within a blended learning course. As they adopt the point of view that the face-to-face modality is at the centre of the course (in large groups as well as in the conversation workshops in small groups), whereas, in actual fact, the course design places the e-learning modality in the heart of the learning process, they cannot understand why the online part of the course is useful, how the modalities are combined, and why they should play a role at a distance. As a consequence, they never, or almost never, play the role of online tutor. If they do so, 
they limit this role to marking written work. And, when they do manage to create links with the online elements when delivering the face-to-face sessions, these links are mainly based on grammar and vocabulary.

This reveals another difficulty regarding teachers' comprehension of the course design: most of them do not seem familiar with the task-based approach on which these courses, in application of the Common European Framework of Reference for Languages, are based. They do not consider the tasks, with the methodological or preparative work they offer, as a possible way to make a link between the different learning modalities within the blended learning course.

We can clearly note a difference where the few tutors with experience as course designers of online/partly online programmes are concerned. Indeed, their understanding of what the face-to-face sessions in the blended learning settings can be used for is much closer to the point of view of the course designers and coordinators ${ }^{2}$. For the latter, these sessions make sense only in combination with the online part; they can complement it (e.g. when focusing on oral communication skills whereas online students do mostly written and asynchronous work), allow tuition modes to be varied (e.g. when giving students time to ask an oral question on the course that they would not take time to write via e-mail), resolve problems (e.g. a technical difficulty), provide initial information on how the course works, foster methodological skills in order to prepare and enhance task completion, provide opportunities to students to get in touch, and can also give them time to allow their teamwork to progress.

In our interviews, most of the tutors insisted on the lack of student

involvement in the online part of their blended learning course. Many reasons for this

$2 \quad$ Even though one of these two tutors still has difficulties with the integrated combination of online and face-to-face modalities, since she still considers the face-toface sessions as the most important ones, and since she admits her understanding of the task-based approach is not deep enough to entirely comprehend the relatively complex design of the course. 
can be found, such as too few credits allocated to the course, and proportionally too much personal work requested. Additionally, however, a tutor whose global understanding of the course design is only partial, even if he is very motivated as many of our tutors are, will undoubtedly have difficulties in presenting the way the course works to the students. The latter will be far less likely to feel involved in a course when it is not clear to them how the course works and what is expected of them.

Our findings will help to define future tutor training and assistance: the understanding of the task-based approach and of the distance-centered design, as well as most of the aspects which enhance tutor involvement, can be sustained with adequate tutor training. In parallel to Ernest \& Hopkins' (2006) findings, this training should include the opportunity for tutors to meet regularly and to share their reflection, allowing them at the same time to constitute a learning community. It should moreover be task-based and combine face-to-face and tutored distance learning modalities, so as to allow the tutors to forge their own experience within a blended learning course and to improve their understanding of this type of course design and of the kind of tuition that can effectively help the students.

\section{References}

Allan, B. (2007). Blended Learning Tools for Teaching and Training. London: Facet Publishing.

Bañados, E. (2006). A blended-learning pedagogical model for teaching and learning EFL successfully through an online interactive multimedia environment. CALICO Journal Vol. 23, $n^{\circ} 3,533-550$.

Bernard, M. (1999). Penser la Mise à Distance en Formation. Paris: L'Harmattan.

Bersin, J. (2004). The blended learning book: Best Practices, Proven Methodologies, and Lessons Learned. San Francisco, CA: Pfeiffer Publishing.

Bonk, C., \& Graham, C. (Eds.) (2006). Handbook of blended learning: Global Perspectives, local designs. San Francisco, CA: Pfeiffer Publishing.

Council of Europe (2001). Common European Framework of Reference for Languages: Learning, Teaching, Assessment. Cambridge: Cambridge University Press. 
Dalsgaard, C., \& Gods, M. (2007). Transforming traditional lectures into problembased learning: challenges and experiences. Open Learning 22(1), 29-42.

Deschryver, N. (2008). Interaction sociale et expérience d'apprentissage en formation hybride (Doctoral dissertation). Université de Genève, FAPSE, Section for Educational Sciences. Retrieved from http://tecfa.unige.ch/perso/deschryv/doc/these deschryver.pdf

Driscoll, M. (2002). Blended Learning: let's get beyond the hype, E-learningmag, 1 March. Retrieved from http://elearningmag.com/ltimagazine

Ernest, P., \& Hopkins, J. (2006). Coordination and Teacher Development in an Online Learning Environment, CALICO Journal Vol. 23, $n^{\circ} 3$, 551-586.

Garrison, D.R., \& Kanuka, H. (2004). Blended Learning: Uncovering its Transformative Potential in Higher Education. The Internet and Higher Education 7(2), 95-105.

Ginnis, P., \& Ellis, R. (2007). Quality in blended learning: Exploring the relationships between on-line and face-to-face teaching and learning, The Internet and Higher Education, 10 (1), 53-64.

Giugni, S. (2007, october). Percorsi didattici di apprendimento delle lingue in elearning e blended learning oggi: community, apprendimento cooperativo e informal learning. Paper presented at the meeting ILSA: Processi di apprendimento linguistico e gestione della classe ad abilità differenziate. Published in 2009, Atti del XVI Convegno nazionale ILSA, Firenze, 27 ottobre 2007, 05-112. Retrieved from http://www.itasmatteoricci.it/servizi/intercultura/ilsa_atti_convegno.pdf

Graham, C. R. (2006). Blended learning systems: definition, current trends, and future directions. In C. J., Bonk \& C.R., Graham (Eds.). Handbook of blended learning: Global Perspectives, local designs. San Francisco, CA: Pfeiffer Publishing.

Guillet, B., \& Roupié, C. (2008). Retour d'expériences d'une formation hybride. Perspectives d'évolution. Quelle définition de la fonction tutorale dans ce type de dispositif ?. Tice 2008, actes du colloque, 27, 28, 29 octobre 2008, 176188. Retrieved from http://tice2008.instituttelecom.fr/archive/45/TICE2008 Actes web09.pdf

Harker, M., \& Koutsantoni, D. (2005). Can it be as effective? Distance versus blended learning in a web-based EAP programme. ReCALL,17(2), 197-216.

Hauck M., \& Stickler, U. (2006). What Does It Take to Teach Online, CALICO Journal Vol. 23, $n^{\circ} 3$, pp. 463-475.

Henri, F., \& Lundgren-Cayrol, K. (2001). Apprentissage collaboratif à distance. Pour comprendre et concevoir les environnements d'apprentissage virtuels. SainteFoy : Presses de l'Université du Québec.

Hughes, G. (2007). Using blended learning to increase learner support and improve retention. Teaching in Higher Education, 12 (3), 349-363.

Jacquinot, G. (1993). Apprivoiser la distance et supprimer l'absence ? ou les défis de la formation à distance. Revue Française de Pédagogie, $n^{\circ}$ 102, Paris, 1993, 55-67.

Jézégou, A. (1998). La formation à distance : enjeux, perspectives et limites de l'individualisation. Paris: L'Harmattan.

Kerres, M. \& DE WITT, C. (2003). A Didactical Framework for the Design of Blended Learning Arrangements. Journal of Educational Media, 28(2-3), 101113. 
Lignon, E., \& TEA, E. (2010). Gérer les contraintes d'une formation hybride : le cas du dispositif « EnForCE ». Did\&Tice, Actes de la journée d'études Didactique des langues et Tice, 26 mars 2010, 15-32, Université StendhalGrenoble 3. Retrieved from http://lansad.ugrenoble3.fr/99419392/0/fiche pagelibre/

MacDonald, J., \& McAteer, E. (2003). New approaches to supporting students: strategies for blended learning in distance and campus-based environments. Journal of Educational Media, 28 (2-3), 129-146.

MacDonald, J. (2008). Blended learning and online tutoring. Planning learner support and activity design. USA/England: Gower Publishing Company.

Means, B., Toyama, Y., Murphy, R., Bakia, M., Jones, K. (2009). Evaluation of evidence-based practices in online-learning. A meta-analysis and review of online learning studies. U.S. Department of Education. Retrieved from http://www.ed.gov/rschstat/eval/tech/evidence-based-practices/finalreport.pdf.

Motteram, G. (2006). Blended education and the transformation of teachers: a longterm case study in postgraduate UK Higher Education. British Journal of Educational Technology, 37(1), 17-30. Retrieved from http://www.blackwellsynergy.com/doi/abs/10.1111/j.1467-8535.2005.00511.x

Murphy, P. (2003). The hybrid strategy: Blending face-to-face with virtual instruction to improve large section courses. University of California Regents. Teaching, Learning, and Technology Center. Retrieved from http://www.uctltc.org/news/2002/12/feature print.html

Neumeier, P. (2005). A closer look at blended learning - parameters for designing a blended learning environment for language teaching and learning. ReCALL, 17(2), 163-178.

Nissen, E. (2009a). Accompagnement dans une formation à distance et dans une formation hybride: Analyse de pratiques, in Rivens Mompean, A., Barbot, MJ. (coord.). Dispositifs médiatisés en langues et évolutions professionnelles pour l'accompagnement-tutorat. Villeneuve d'Ascq: Université Lille 3, édition CEGES.

Nissen, E. (2009b). Formation hybride vs. présentielle en langues : effets sur la perception des apprenants liés au mode de formation et à l'encadrement pédagogique. Les Cahiers de l'Acedle, vol. 6, $n^{\circ} 1,197-220$. Retrieved from http://acedle.org/spip.php?article2444

Nissen, E. (2011). Analyser les rôles du tuteur dans une formation hybride: distinguer les interactions verbales à distance et en présentiel. In Nissen, E., Poyet, F., Soubrié, T. (coord.), Interagir et apprendre en ligne. Grenoble: Ellug.

Quintin, J.-J., Porco, F., Floquet, C., Touzé, J., Depover, C. (2001). Learning Platform Esprit : Environnement scénarisé d'apprentissage interactif à distance. Unit for educational technology, university of Mons-Hainaut.

Romano, J., Wallace, T.L., Helmick, I.J., Carey, L.M., Adkins, L. (2005). Study procrastination, achievement, and academic motivation in web-based and blended distance learning. The Internet and Higher Education, 8(4), 299-305.

Rösler, D., \& Würffel, N. (2010). Blended Learning im Fremdsprachenunterricht, Fremdsprache Deutsch, $n^{\circ} 42,5-11$.

Rossett, F., Douglis, R., Frenzee, V. (2003). Strategies for Building Blended Learning. ASTD Learning Circuits, June 2003. Retrieved from http://www.essentiallearning.net/news/Strategies\%20for\%20Building \%20Blended $\% 20$ Learning.pdf 
Rovai, A. P., \& Jordan, H. M. (2004). Blended Learning and Sense of Community: A comparative analysis with traditional and fully online graduate courses. The International Review of Research in Open and Distance Learning, 5(2). Retrieved from http://www.irrodl.org/index.php/irrodl/article/view/192

Saunders, P., \& Werner, K. (2002). Finding the right blend for effective learning. Learning technology, 4 (2). Retrieved from http://www.ieeetclt.org/issues/april2002/index.html\#2

Singh, H. (2003). Building Effective Blended Learning Programs. Educational Technology, 43, 51-54.

Soubrié, T. (2008). La difficile articulation du présentiel et de la distance dans le cadre d'un cours hybride en master. Apprentissage des langues et systèmes d'information et de communication (Alsic), vol. 11, $n^{\circ} 2,105-127$. Retrieved from http://alsic.u-strasbg.fr/v11/soubrie/alsic v11 03-pra2.htm

Strake, E. (2007). A road to understanding: A qualitative study into why learners drop out of a blended language learning (BLL) environment. ReCALL, 19/1, 57-78.

Staddon, S. (2001). Going online: Can Language Teachers Go it Alone and is it worth the Heartache?. In U. Felix (ed.), Beyond Babel: Language Learning Online (81-97). Melbourne: Language Australia Ltd.

Thorne, K. (2002). Blended Learning: How to Integrate Online and Traditional Learning, London: Kogan Page.

Whitelock, D., \& Jelfs, A. (2003). Editorial: Journal of Educational Media Special Issue on Blended Learning. Journal of Educational Media, 28(2-3), 99-100.

\section{Acknowledgements}

The authors are grateful to the students, the tutors and their colleagues at the Lansad Department at Stendhal University. 